\title{
Yetişkin Eğitimi Kapsamında Okuma Yazma Kurslarına Katılan Kadın Kursiyerlerin Günlük Yaşamlarındaki Değişimler
}

\section{Changes in the Daily Lives of Women Trainees Attending Literacy Courses in The Scope of Adult Education}

\author{
Emin Tamer Yenen, ${ }^{\mathrm{a},{ }^{*}}$ Mehmet Yıldırım ${ }^{\mathrm{b}}$

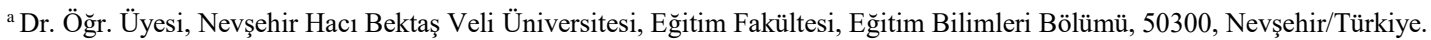 \\ ORCID: 0000-0003-2359-3518 \\ ${ }^{\text {b }}$ Mdr. Yrd., Nevşehir Merkez İlçe Halk Eğitimi Merkezi, 50300, Nevşehir/Türkiye. \\ ORCID: 0000-0001-7915-6590
}

\begin{tabular}{l} 
MAKALE BİLGİSİ \\
\hline Makale Geçmişi: \\
Başvuru tarihi: 15 Kasım 2019 \\
Düzeltme tarihi: 09 Aralık 2019 \\
Kabul tarihi: 25 Aralık 2019 \\
\hline Anahtar Kelimeler: \\
Halk Eğitim Merkezi \\
Kadın Kursiyerler \\
Okuryazarlık \\
Yetişkin Eğitimi
\end{tabular}

\section{A R T I C L E I N F O}

\section{Article history:}

Received 15 November 2019

Received 09 December 2019

Accepted 25 December 2019

\author{
Keywords: \\ Public Education Center \\ Women Trainees \\ Literacy \\ Adult Education
}

ÖZ

Bu çalışma, yetişkin eğitimi kapsamında okuma yazma kursuna katılan kadın kursiyerlerin günlük hayatlarında meydana gelen değişimleri incelemeyi amaçlamaktadır. Çalışmada nitel araştırma yöntemlerinden fenomonoloji deseni kullanılmıştır. Araştırmanın çalışma grubunu Nevşehir Halk Eğitimi Merkezi'nin okuma yazma kurslarına katılan 12 kadın kursiyer oluşturmuştur. Çalışmada veri toplama aracı olarak yarı yapılandırılmış görüşme formu kullanılmıştır. Veriler 2018-2019 eğitim-öğretim yılı bahar döneminde okuma-yazma kurslarına katılan kadın kursiyer ile yapılan görüşmeler aracılığıyla toplanmıştır. Elde edilen veriler içerik analizi yöntemiyle çözümlenmiştir. Çalışmanın sonucunda, katılımcıların günlük hayatta işlerini tek başına halletmeye başladıkça özgüven kazandıkları görülmüştür. Okuma yazma öğrenen kadınlar geleceğe yönelik planlarında yenilikler yapmışlar, iş yeri açma ve ileriki öğrenimlerine devam etme gibi kendilerine yeni hedefler koymuşlardır.

\begin{abstract}
A B S T R A C T
This study aims to examine the changes in the social life of women trainees who participated in literacy courses in the scope of adult education. Phenomonology design, one of the qualitative research methods, was used in the study. The study group of the research consisted of 12 female trainees who attended the literacy courses in Nevşehir Public Education Center. Semi-structured interview form was used in the study. The data were collected through interviews with female trainees who attended literacy courses in the spring semester of 2018-2019 academic year. The obtained data were analyzed with content analysis method. As a result of the study, it was seen that the participants gained self-confidence as they started to do their job alone in daily life. Women who learned to read and write made innovations in their plans for the future and set new goals for themselves, such as opening a workplace and continuing their further education.
\end{abstract}

\section{Giriş}

Okuma yazma becerileri, toplumsal düzenin ilk kurulduğu zamanlarda sadece seçkin bir zümreye ait bir hak olarak görülmekteyken, günümüzde bütün toplumun okuryazar olması amaçlanmaktadır. 21. yüzyılda teknolojik gelişmelerin hızla artması ile bilgi kaynakları da giderek çoğalmış ve zenginleşmiştir. Ancak bilgi, hâkim olunabildiği ve kullanılabildiği ölçüde yarar sağlamaktadır. Bilgiyi elde etmede en önemli araç, okuma eylemini gerçekleştirmedir (Çağlayan, 2016). Okuryazarlık bireysel ya da teknik bir beceri olmasının yanında toplumun içinde gerçekleşen bir sosyal pratiktir. Eğitimsel ortamlarla birlikte, okuryazarlığın bireylerin gündelik yaşamlarındaki etkilerine de odaklanılmalıdır (Yıldız, 2011). Atatürk, modern hayatın en temel becerilerinden olan okuma yazmanın önemini

\footnotetext{
*Sorumlu yazar/Corresponding author

e-posta: tamer-yenen@hotmail.com
} 
Cumhuriyetin ilk yıllarında 1925 'de Kastamonu'da yaptığı konuşmada, ülkede artık karma eğitimin uygulanacağını, zaten çok düşük okuma yazma oranlarının arttırılırken, cinsiyet ayrımının da ortadan kaldırılmaya çalışılmasının ve kadınların da erkekler kadar eğitim faaliyetlerine katılmasının büyük önem arz ettiğini açıkça belirtmiştir (Sabah, 2006). Okuma yazma gibi temel eğitim faaliyetleri örgün eğitim kurumları aracılığıyla verilmektedir. Ancak öğretim, sadece okullarda düzenlenen örgün eğitim faaliyetleri ile sınırlı değildir. Örgün eğitimin dışında kalmış bireylerin sosyal hayatta ihtiyaç duydukları bilgi, beceri ve yeterlikleri kazandırmak amacıyla, yaygın eğitim faaliyetleri kapsamında da belirli bir plan ve program dâhilinde, belirlenen hedeflere yönelik programlarla okul dişında da sürdürülebilmektedir (Köksal, 2017) Bu doğrultuda, 1928 yılında yapılan alfabe değişikliğinden sonra yeni harflerle okuma yazma öğretmek amacıyla önceden beri çalışmalarını sürdüren Halk Mektepleri, Halk Dershaneleri ve Gece Kursları Millet Mektepleri'ne dönüştürülerek bir okumayazma kampanyası başlatılmış, 16-45 yaşları arasında olanların okuma-yazma kurslarına katılmaları zorunlu kılınmıştır. Tüm ülke bir okula dönüştürülerek, okuyup yazabilen nüfusun oranı 1928 'den yaklaşı $\% 8$ 'den, 1935 'te \%20'nin ve savaşın sonunda 30'un üzerine çıkarılmıştır (Okçabol, 1994).

Yetişkin eğitimi kapsamında açılan okuma yazma kurslarına örnek olarak 1932'de kurulmaya başlanan Halkevleri verilebilir. Halkevleri, okuma yazma çalışmaları kapsamında, farklı eğitim düzeyinde birçok gruba katkıda bulunmuştur (Altunya, 2009). Cumhuriyet döneminde okuma-yazma seferberliklerinin asıl amaçlarından biri de devrimleri halka benimsettirmektir. Bu amaçla Türkiye'nin birçok şehrinde (Afyon, Ankara, Aydın, Bolu, Bursa, Çanakkale, Denizli, Diyarbakır, Eminönü, Eskişehir, İzmir, Konya, Malatya ve Samsun) Halkevleri kurulmuştur. Bir yandan okuma yazma oranı $\% 8$ ile $\% 12$ arasında değişen halkın, okuma yazma oranı yükseltilmeye çalışılırken diğer yandan da Kemalist ideoloji ve devrimler yerleştirilmeye çalışılmıştır (Yıldız, 2009). Ulusal düzeyde yedi kitlesel okuma-yazma kampanyası (1928, 1960, 1971, 1981, 2001, 2008, 2018 yıllarında) düzenlenmiştir. Böylece Cumhuriyetin kuruluş yıllarında yaklaşık \%10 olan okuryazarlık oranı, 1980 yılında 67,2'ye, 1990'da \%80'e, 2000 yılında \% 86,5'e, 2006 yılında da \%88'ye ulaşmıştır. Günümüzde ise okuma yazma oranları 2008 yılında \% 90'a, 2015 yılında 95,6'ya, 2016'da 95,9'a yükselmiştir (Gökçe ve Yıldız, 2018). Sonuç olarak okuma yazma oranlarında giderek yükselen bir ivme yakalanmıştır. Ancak bu sonuçlar arasındaki dikkat çeken bir detayı atlamamak gerekir. Ülkemizde 2018 yılı verilerine göre okuma yazma bilmeyen 2.482.432 kişinin \%84'ünü kadınlar oluşturmuştur (TUİK, 2018). Bu sonuç, ülkemizde sayıları milyonlarla ifade edilen okuma yazma bilmeyen insanların büyük çoğunluğunu kadınların oluşturduğunu göstermektedir. Erçetin ve Arifoğlu (2016) da çalışmalarında, Herkes İçin Eğitim (Education for All-EFA) hareketinin 2015 Türkiye hedefleri doğrultusunda yapılan çeşitli çalışmaların okuma yazma bilmeyenlerin oranını dönem sonu itibariyle \% 5'in altına düşürdüğünü, ancak 15 yaş ve üstü nüfusta hala azımsanamayacak sayıda vatandaş bulunduğunu ve bunların büyük bir kısmını kadınların oluşturduğunu belirtmişlerdir. Erçetin ve Arifoğlu'na (2016) göre, 2015 sonrası eğitim gündemi kapsamında özellikle kadınların sosyoekonomik statüsü ve eğitimsel geçmişi gibi durumların gözetilerek hazırlanacak olan projeler ve kurslar ile yetişkin okuryazarlığında ve cinsiyet eşitliğinde olumlu bir ivme elde edilmesi sağlanabilir.

Okuma yazma kursuna katılan grubun yetişkin olduğu dikkate alındığında, yetişkinlerin temel özelliklerini de göz önünde bulundurmak gerekmektedir. Yetişkin eğitiminde zorlama değil gönüllü katılım esastır. Yetişkinlerin beklentileri karşılanırsa eğitime aktif katılım sağlarlar. Beklentileri karşılanmazsa eğitimin dışında kalmayı tercih edebilirler (Knowles, 1980). Yetişkinler eğitim ortamına beklentilerini ve tecrübelerini de beraberinde getirirler. Diğer bir ifade ile yetişkinlerin tecrübeleri eğitim ortamına zenginlik katar. Karşılıklı öğrenmeyi kuvvetlendirir. Dolayısıyla yetişkinlerin öğrenme zamanı, ön yargıları ve düşünceleri onları örgün eğitim öğrencilerinden farklı kılmaktadır (Merriam, 2004). Yetişkinler sorun merkezli bir eğitimi, konu merkezli eğitime tercih ederler. Yetişkinlerde dişsal güdülenmeden ziyade içsel güdülenme ön plandadır (Gökçe, 2016; Holton, Swanson ve Naquin, 2001; Knowles, 1996; Merriam, 2017).

Eğitim, tüm insanlara tanınmış temel bir haktır ve bu sebepten hem erkek hem de kadınların eğitim alma imkânları açısından bir eşitsizliğin olmaması tüm toplumlar için gereklidir. Buna rağmen dünya ve Türkiye genelinde cinsiyet açısından önemli eşitsizliklerin olduğu ve günümüzde bu eşitsizliğin tam anlamıyla giderilemediği bir gerçektir (Erçetin ve Arifoğlu, 2016). Eğitim görmenin en temel hak olduğunu bilenler, çoğunlukla bu hakk1 kullanabilecek bilince sahipken, okuryazarlığı olmayanlar ise bu hakk1 arayamayan ve kullanmayan sessiz bir kitleyi oluşturmaktadır (Yıldız, 2009). Bu bağlamda okuryazarlığın temel bir beceriden çok sosyal bir olgu olduğu ve bireylerin gündelik hayatlarına doğrudan bir etkisinin olduğu göz önünde bulundurulmalıdır. Freire (2018) de okuryazar olmanın sadece okuma ve yazma öğrenilmesi ile sınırlı olmadığını; aynı zamanda okuma yazmanın nasıl kullanılacağından bireyin sosyo-ekonomik statüsü ve toplumsal cinsiyetine varıncaya kadar toplumsal yaşamındaki birçok konu ile ilişkili olduğunu vurgulamaktadır. Okuma yazma kurslarına katılanların sadece okuma yazma becerilerine odaklanmamak, kişiselkültürel arka planlarını ve gündelik yaşam pratiklerini de incelemek gerekmektedir (Yıldız, 2011). Bu doğrultuda çalışmada, yetişkin eğitimi kapsamında okuma yazma kurslarına katılan kadınların okuma yazma kurslarına katılma sebeplerine ve okuma yazma ögrrendikten sonra ev hayatlarında ve yakın çevre ile ilişkilerinde, gündelik hayatlarında ve geleceğe yönelik planlarında ne gibi değişikler olduğuna ilişkin görüşlerinin incelenmesi amaçlanmıştır. $\mathrm{Bu}$ amaç doğrultusunda aşağıdaki sorulara yanıt aranmıştır:

1- Kadın kursiyerlerin okuma yazma kursuna katılma sebepleri nelerdir?

2- Kadın kursiyerler okuma yazma kursuna katıldıkları süreç boyunca ailelerinden, komşu ve arkadaşlarından nasıl tepkiler aldılar?

3- Okuma yazma kursuna katıldıktan sonra kadın kursiyerlerin günlük hayatlarında ne gibi değişiklikler oldu? 
4- Bu kursa katıldıktan sonra kadın kursiyerlerin geleceğe yönelik planlarında ne gibi değişiklikler oldu?

\section{Yöntem}

$\mathrm{Bu}$ bölümde, araştırma deseni, çalışma grubu, veri toplama arac1, verilerin toplanması ve verilerin analiz edilmesi sürecine ilişkin bilgiler sunulmaktadır.

\subsection{Araştırmanın Deseni}

$\mathrm{Bu}$ araştırmada nitel araştırma yöntemlerinden fenomenoloji deseni kullanılmıştır. Olgu bilim olarak da adlandırılan fenomenoloji yöntemi ile kadın kursiyerlerin okuma yazma kursuna katılma sebeplerinin ve gündelik hayatlarındaki değişimlerin gerçekte neler oldu araştırılmıştır. Fenomenoloji "gerçek nedir?" sorusuna cevap arayan bir yöntemdir ve farkında olduğumuz ancak derinlemesine ve ayrıntılı bir anlayışa sahip olmadığımız olgulara odaklanır (Şimşek ve Yıldırım, 2011). Fenomenoloji tanımlayıcı bir araştırmadır. Fenomenoloji yaklaşımın temelini bireysel tecrübeler oluşturmaktadır. $\mathrm{Bu}$ yaklaşımda araştırmacı katılımcının kişisel (öznel) tecrübeleri ile ilgilenmekte, bireyin algılamaları ve olaylara yükledikleri anlamları incelemektedir (Creswell, 2007).

\section{2. Çalışma Grubu}

Katılımcılar, 2018-2019 eğitim öğretim yılında Nevşehir ili Merkez İlçesi Halk Eğitimi Merkezi Müdürlüğünün açmış olduğu okuma yazma kurslarına katılıp, okuma yazma öğrenen, yaşları 47 ile 63 arasında değişen 12 kadın kursiyerden oluşmaktadır. Kursiyerler, gönüllülük esasına göre araştırmaya katılmışlardır. Araştırmada çalışma grubu belirlenirken amaca dayalı örnekleme yöntemlerinden ölçüt örnekleme kullanılmıştır. Bu araştırmadaki ölçüt, yetişkin eğitimi kapsamında Halk Eğitim Merkezindeki okuma yazma kurslarına katılan kadın kursiyerlerdir.

Tablo 1. Katılımcıların Demografik Bilgileri

\begin{tabular}{|c|c|c|c|c|c|c|c|}
\hline Kadın & Evli & Bekâr & $\begin{array}{l}\text { Annesi } \\
\text { Okuryazar } \\
\text { Olan }\end{array}$ & $\begin{array}{c}\text { Babas1 } \\
\text { Okuryazar } \\
\text { Olan }\end{array}$ & $\begin{array}{l}40- \\
50 \\
\text { Yaş }\end{array}$ & $\begin{array}{c}50- \\
60 \\
\text { Yaş }\end{array}$ & $\begin{array}{c}60 \\
70 \\
\text { Yaş }\end{array}$ \\
\hline 12 & 12 & 0 & 0 & 2 & 3 & 5 & 4 \\
\hline
\end{tabular}

Tablo 1'de görüldüğü üzere katılımcıların hepsi evlidir ve 40 yaşın üzerindedir. Tüm katılımcıların annesi okuma yazma bilmezken, sadece ikisinin babası okuryazardır.

\subsection{Veri Toplama Arac1}

Çalışmada veri toplama aracı olarak yarı yapılandırılmış görüşme formu kullanılmıştır. Araştırmacılar tarafından geliştirilen form iki bölümden oluşmaktadır. Birinci bölüm katılımcılara ait demografik bilgileri (medeni hali, ebeveyn okuryazarlık durumu, yaş) içerirken; ikinci bölüm katılımcıların kursa katılma sebeplerine, okuma-yazma kurslarına katıldığı süreç boyunca aileden, komşu ve arkadaşlarından gördüğü tepkilere, okuma yazma kurslarına katılmanın hayatlarına neler kattığına ve okuma yazma öğrenmenin geleceğe yönelik planlarını nasıl etkilediğine ilişkin düşüncelerini açığa çıkaran açık uçlu sorulardan oluşmuştur. Görüşme formu oluşturma sürecinde ilgili literatür incelenmiş ve uzman görüşlerine başvurulmuştur. İki Eğitim Programları ve Öğretim alanı, birer kişi de Eğitim
Yönetimi ve Sınıf Öğretmenliği alanı uzmanı olmak üzere toplamda dört uzmanın görüşleri neticesinde, soruların daha anlaşılır bir düzeyde yazılmasına karar verilmiş ve görüşme formunun son şekli verilmiştir. Soruların anlaşılırlığı ve tutarlılığının test edilmesi amacıyla aynı kurslara katılan üç farklı kişiye ön uygulama yapılmıştır. Görüşme görüşme formundaki soruların amaca hizmet ettiği görüldükten sonra verilerin toplanması aşamasına geçilmiştir.

\subsection{Verilerin Toplanmas1}

Veriler 2019 Mart ve Nisan aylarında Nevşehir ili Merkez ilçesi Halk Eğitim Merkezi Müdürlüğünde okuma-yazma kurslarına katılan 12 kadın kursiyer ile yapılan görüşmeler aracılığıyla toplanmıştır. Görüşmelere geçilmeden önce ilgili müdürlükten gerekli izinler alınmıştır. Görüşmelerde ortalama her kursiyer için 15 dakika vakit ayrılmıştır. Katılımcıların sorulara ilişkin görüşlerine müdahale edilmeksizin verdikleri cevaplar kurs eğitimcileri ve araştırmacıların yardımı ile yazılmıştır. Soruların gerçek ve samimi bir şekilde yanıtlanmasının araştırma sonuçları açısından önemi özellikle belirtilmiştir.

\subsection{Verilerin Çözümlenmesi}

Veriler çözümlenirken katılımcılar gerçek isimlerinden farklı olarak rumuz isimlerle kodlanmıştır. Örneğin görüşme formunu dolduran katılımcılar Ayşe, Fatma, Necla gibi rumuz isimlerle kodlanmıştır. Araştırma verileri içerik analizi yöntemiyle çözümlenmiştir. İçerik analizi, yoğun ve karmaşık olan nitel verileri birbiri ile tutarlı hale getirerek belirli kavramlar ve temalar çerçevesinde anlamlandırma çabasıdır (Patton, 2002). Elde edilen veriler tema, alt tema ve kodlar aracılığıyla kategorize edilmiştir. Araştırmada inanırlığın arttırılması adına yapılan görüşmelerden alıntılar yapılmıştır.

\section{6 Çalışmanın Sınırlıkları}

Bu çalışma 2018-2019 eğitim öğretim yılında Nevşehir ili Merkez İlçesi Halk Eğitimi Merkezi Müdürlüğünün açmış olduğu okuma yazma kurslarından elde edilen veriler ile sinirlidır.

\section{Bulgular}

$\mathrm{Bu}$ bölümde araştırmada elde edilen bulgulara yer verilmiştir.

3.1 Katılıcıların Okuma-Yazma Kursuna Katılma Sebeplerine İlişkin Bulgular

$\mathrm{Bu}$ temada yetişkin eğitimi kapsamında okuma yazma kursuna katılan kadın kursiyerlerin kursa katılma nedenlerine ilişkin görüşleri incelenmiştir. Elde edilen verilerden oluşturulan alt tema ve kodlar Tablo 2'de sunulmuştur. 
Analiz sonuçlarından çıkan temalara bakıldığında, kadın kursiyerlerin kurslara katılma sebeplerinin çeşitlilik gösterdiği, daha çok gündelik hayatlarındaki temel ihtiyaçları tek başlarına giderebilmeleri için kurslara

Tablo 2. Kadın Kursiyerlerim Okuma Yazma Kursuna Katılma katıldıkları anlaşılmaktadır.

Sebepleri

\begin{tabular}{|c|c|c|}
\hline Tema & Alt Tema & Kodlar \\
\hline \multirow{11}{*}{ 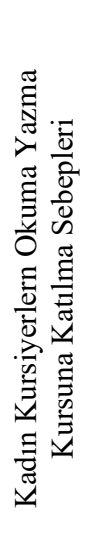 } & \multirow{3}{*}{ Kişisel Gelişim } & Kur'an-1 Kerim Meali okumak $(n=5)$ \\
\hline & & Yeni bilgiler öğrenmek $(n=3)$ \\
\hline & & Toplum içinde küçük düşmemek $(\mathrm{n}=2)$ \\
\hline & \multirow{2}{*}{ Ekonomik } & İş başvurusu yapabilmek(n=2) \\
\hline & & İş yeri açmak $(n=2)$ \\
\hline & \multirow{7}{*}{$\begin{array}{l}\text { Kendine } \\
\text { Yetebilme }\end{array}$} & Gazete vs. okumak $(n=6)$ \\
\hline & & Ulaşımda sorun yaşamamak $(n=5)$ \\
\hline & & Hastaneye tek başına gitmek $(n=5)$ \\
\hline & & Mesaj yazabilmek $(n=2)$ \\
\hline & & Alışverişte zorlanmamak $(\mathrm{n}=2)$ \\
\hline & & Tek başına oy kullanmak (n=2) \\
\hline & & Ehliyet almak $(\mathrm{n}=1)$ \\
\hline
\end{tabular}

Okuma yazma kursuna katılan kadınlar, okuma yazma öğrenmeyi isteme sebeplerini, en çok televizyonlardaki yazıları, gazeteleri ve kitapları okuyabilmek olarak belirtmişlerdir. Bununla birlikte katılımcılar günlük hayattaki işlerini kolaylaştırmaya yönelik faaliyetler olan, hastanedeki işlemlerini tek başlarına halledebilmek, otobüse binerken zorluk yaşamamak ve sürekli birilerine sormamak için okuma yazma öğrenmeyi istemektedirler. Ayrıca önemli bir kısım da Kuran meallerini okuyabilmek için okuma yazma öğrenmek istediğini belirtmiştir. Katılımcı görüşlerinden bazı örnekler aşağıda sunulmuştur:

\begin{abstract}
"Hastaneye giderken, bineceğim otobüsü durakta bekleyenlere soruyorum. Pazara çıktığımda etiketlerde yazanları okuyamıyorum, artık kimseye danışmadan kendi kendime alışveriş yapmak istiyorum.” (Sakine).

"Evde çocuklar kitap açtığında, ben okuyamıyorum diye utanıyorum. Okumayı ögrendiğimde, ilk önce Kur'an-ı Kerim mealleri okumak istiyorum. Bugüne kadar hep ya Arapça okudum ya da başkalarının okuduğunu doğru diye dinledim. Bunlart yaparken ayn zamanda ehliyet de almak için okuma yazmayı ögrenmeyi çok istedim." (Fatma).
\end{abstract}

Katılımcıların bu temaya ilişkin vermiş olduğu diğer farklı cevaplar; insanların kendilerine cahil demelerine kızıp ayrıca bu durumdan utandığını belirtenler, her işte komşularına soru sormaktan usandım, cep telefonu ve mesajlaşma sistemini kullanmak istiyorum, seçimlerde oy kullanırken zorlanıyorum, ehliyet almak için okuma yazmayı bilmem gerekir, iş başvurusu yapmaya dahi çekiniyorum, market alışverişlerinde gerekli oluyor şeklinde sıralanmıştır. Bu temaya ilişkin katılımcı görüşlerinden bazıları aşağıda verilmiştir:

"Oy vermeye gitmeden önce evde çocuklar, mührü nereye basacağımı şekillerden, parti simgelerinden tarif ediyor. Küçücük oğlumun bile bu tarifi yapmasından çok utaniyorum. Bu durumlarda kendimi insan sinıfindan görmüyorum." (Sabahat).

"Eşim bir şey anlatırken, klzdiğında "cahil insan, bir şeyden anlamıyorsun!” dediğinde çok huzursuz oluyorum." (Süheyla).
3.2 Okuma Yazma Kursu Sürecinde Aile, Komşu ve Arkadaş Tepkilerine İlişkin Bulgular

Bu temada kadın kursiyerlerin okuma yazma kursu sürecinde yakın çevrelerinden aldığı tepkilere ilişkin elde edilen bulgular sunulmuştur. Elde edilen veriler iki ayrı bölümde incelenmiştir. İlk bölümde ailenin, ikinci bölümde komşu ve arkadaşların tepkileri ele alınmıştır. Kadın kursiyerlerin kursa katılmalarına ilişkin ailelerinin vermiş olduğu tepkiler Tablo 3'te sunulmuştur.

Tablo 3. Kadın Kursiyerlerin Kursa Katılımlarına İlişkin Ailelerinin Verdiği Tepkiler

\begin{tabular}{lll}
\hline Tema & Alt Tema & Kodlar \\
\hline & $\begin{array}{l}\text { Destek } \\
\text { Oldular }\end{array}$ & Motive etme $(\mathrm{n}=7)$ \\
& & Birlikte çalışma $(\mathrm{n}=3)$ \\
& & Yardım etme $(\mathrm{n}=3)$ \\
\cline { 2 - 3 } & Destek & Küçümseme $(\mathrm{n}=1)$ \\
\cline { 2 - 3 } & Olmadilar & Gereksiz bulma $(\mathrm{n}=1)$ \\
\cline { 2 - 3 } & Fikir & Ailem olumlu ya da olumsuz bir fikir \\
& Belirtmediler & belirtmedi $(\mathrm{n}=2)$ \\
\hline
\end{tabular}

Araştırmada katılımcıların çoğu $(n=8)$ ailelerinin okuma yazma öğrenmelerine destek verdiğini belirtmiştir. Yapılan analizlerde ailelerin kadın kursiyerleri kursa katılma noktasında motive ettikleri ve onlara çalışmalarında yardımcı oldukları anlaşılmaktadır. Örnek bir görüş aşağıda sunulmuştur:

"Eșimden çok destek gördüm. Cocuklarım da aynı şekilde çok destekledi. Her gün sabah arabayla eşim beni okula getiriyor. Hatta eșimin yardımıyla her akșam evde 2 tane hikâye kitabı okuyoruz." (Fatma).

Sadece iki katılımcının eşi, eşinin okuma yazma kursuna gitmesini desteklememiştir, iki katılımcı da fikir belirtmediler şeklinde cevap vermiştir. Destek olmadılar temasına ilişkin bir alıntı aşağıda verilmiştir:

"Eşim okuma yazma kursuna gitmemi istemedi. Bu yaşta
ne yapacaksın diye kızd fakat çocuklarımın yoğun
desteğiyle onun direncini kırıp kursa geldim." (Zeynep).

Katılımcıların kursa katılma kararlarına ilişkin komşu ve arkadaşlarının vermiş olduğu tepkilerin frekans dağılımları Tablo 4'te verilmiştir.

Tablo 4. Kadın Kursiyerlerin Kursa Katılımlarına İlişkin Komşu ve Arkadaşlarının Verdiği Tepkiler

\begin{tabular}{lll}
\hline Tema & Alt Tema & Kodlar \\
\hline & & Motive etme $(\mathrm{n}=4)$ \\
& Yardim etme $(\mathrm{n}=2)$ \\
& Gestek & Gereksiz bulma $(\mathrm{n}=5)$ \\
& Olmaḑümseme $(\mathrm{n}=1)$ \\
\hline
\end{tabular}

Tablo 4 incelendiğinde kursa katılımlarına ilişkin katılımcıların komşu ve arkadaşlarından gelen yorumların 
iki alt temada toplandığı görülmektedir. Katılımcıların yarısının yakın çevresi okuma yazma öğrenmelerine destek verirken, yarısı da okuma yazma kursuna gitmelerini onaylamamıştır. Destek verenlerin görüşleri motive etme ve yardım etme kodları altında toplanmıştır. Örneklerden biri şu şekildedir:

"Komşularım okuma öğrenirsen çok güzel olur, okumanın yaşı olmaz, diyerek okuma yazma ögrenmeme destek verdiler" (Sabriye).

Destek olmayanların görüşleri ise gereksiz bulma ve küçümseme kodları altında toplanmıştır. Alıntılardan biri şu şekildedir:

"Arkadaşlarım, gitme bu saatten sonra okusan ne olacak, millet arkandan laf eder dediler" (Sakine).

3.3 Kadın Kursiyerlerin Okuma Yazma Kursuna Katıldıktan Sonra Günlük Hayatlarındaki Değişimlere İlişkin Bulgular

Bu temada kadın kursiyerlerin kursa katıldıktan sonra günlük hayatlarındaki değişimler sorulmuştur. Elde edilen bulgular Tablo 5'te sunulmuştur.

Tablo 5. Kadınların Okuma Yazma Kursuna Katıldıktan Sonra Günlük Hayatlarındaki Değişimler

\begin{tabular}{|c|c|c|}
\hline Tema & Alt Tema & Kodlar \\
\hline \multirow{7}{*}{ 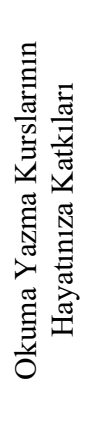 } & \multirow{4}{*}{ Günlük Hayat } & Hastaneye tek başıma gidebiliyorum $(n=5)$ \\
\hline & & Ulaşım işlerini halledebiliyorum $(\mathrm{n}=5)$ \\
\hline & & $\begin{array}{l}\text { Banka işlerini tek başıma halledebiliyorum } \\
(\mathrm{n}=3)\end{array}$ \\
\hline & & Alışveriş işlerini halledebiliyorum $(n=2)$ \\
\hline & Özgüven & Kendime güvenim geldi $(\mathrm{n}=8)$ \\
\hline & Sorgulama & Duyduğum her şeye inanmıyorum $(n=7)$ \\
\hline & $\begin{array}{l}\text { Kendini } \\
\text { Geliştirme }\end{array}$ & İstediğim kitapları okuyabiliyorum $(n=7)$ \\
\hline
\end{tabular}

Okuma yazma kursuna katılan katılımcıların tamamı günlük hayattaki faaliyetlerinde, hastane, telefon, banka, ulaşım, pazar, market gibi işlerde işlerinin kolaylaştığını belirtmişlerdir. Katılımcıların büyük çoğunluğu, artık rahatça kitap okuyabildiğini, Kur'an meallerini okuyabildiklerini belirtmişlerdir.

\begin{abstract}
"Eşimin işten gelme vakti biraz gecikirse, artık telefon açabiliyorum. Pazara çıktığımda artık daha rahatım. Gelinime mektup yazdiğımda, bütün aile çok mutlu oldu." (Sabahat).

"Geçen zor bir hastalık anında, ambulansı kendim aradım. Artık sürekli birilerine bir şey sormak istemiyorum. Doğalgaz, su, elektrik faturalarını da kendim ödediğimde çok mutlu oldum." (Neriman).
\end{abstract}

Bunların dışında katılımcıların büyük çoğunluğu işlerini kendi başlarına halledebildiklerini, kendilerine öz güven geldiğini belirmişlerdir. Ayrıca kadın kursiyerler okuma yazma öğrendiklerinden, dışa bağımlılıklarının azaldığını ve artık her söylenilene inanmadıklarını ifade etmişlerdir.

\footnotetext{
"Şimdi kimseye eyvallahım yok. Nereye gideceksem rahat gidiyorum. Otobüslerin önündeki yazllart okuyabiliyorum. Kendime güvenim geldi artı, kimseye bir şey sormadan işlerimi halledebiliyorum." (Meltem).
}

3.4 Kadın Kursiyerlerin Okuma Yazma Kursuna Katıldıktan Sonra Geleceğe Yönelik Planlarına İlişkin Bulgular

Çalışmada kadın kursiyerlere okuma yazma kursuna katıldıktan sonra geleceğe yönelik planlarında ne gibi değişiklikler olduğu sorulmuştur. $\mathrm{Bu}$ temada kadın kursiyerlerin geleceğe yönelik planlarına ilişkin bulgular incelenmiştir. Elde edilen verilerden oluşturulan alt tema ve kodlar Tablo 6'da sunulmuştur.

Tablo 6. Kadın Kursiyerlerin Okuma Yazma Öğrendikten Sonra Geleceğe Ait Planlarındaki Değişimler

\begin{tabular}{|c|c|c|}
\hline Tema & $\begin{array}{l}\text { Alt } \\
\text { Tema }\end{array}$ & Kodlar \\
\hline \multirow{6}{*}{ 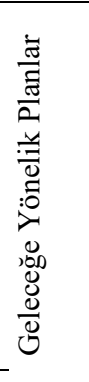 } & $\begin{array}{l}\text { Kişisel } \\
\text { Gelişim }\end{array}$ & $\begin{array}{l}\text { Farklı özelliklerini keşfetme } \\
(\mathrm{n}=3)\end{array}$ \\
\hline & & Günlük tutma $(\mathrm{n}=2)$ \\
\hline & & $\begin{array}{l}\text { Şarkı ve şiir yazma }(n=2) \\
\text { Ehliyet alma }(n=2)\end{array}$ \\
\hline & Eğitim & Eğitime devam etme $(n=7)$ \\
\hline & İş Hayatı & İş yeri açma $(n=2)$ \\
\hline & & İş başvurusu yapma $(n=2)$ \\
\hline
\end{tabular}

Katılımcıların tamamı kurslardan çok memnun olduklarını ve eğitimlere devam ederlerse kendilerini geliştirebileceklerini ifade etmişlerdir. Kadın kursiyerler artık kendilerini eskisi gibi her söylenilene inanmayan biri olarak gördüğünü bundan sonra araştırarak, okuyarak gelecekte çok bilgili bir kişi olmak istediklerini belirtmişlerdir. Örnek görüşlerden bazıları şöyledir:
“ Dinlediğim şeyleri, araştırma imkânım oldu. Artık her duyduğuma inanmiyor, duyduklarım doğru mu diye baklyorum." (Necla).
"İleride şarkl, şiir yazıp farklı bir gelecek sürdürmek istiyorum” (Meltem).
“Artık günlük tutmak istiyorum. Her şeyi yazmak istiyorum." (Fatma).
“Ehliyet almak, işyeri açmak istiyorum." (Sabriye).

Katılımcılardan yedi kişi 2. kademe okuma yazma kursu bittikten sonra ortaokul, lise hatta üniversite okumak istediğini ifade etmişlerdir.

\section{"Ĕ̌itime kaldı̆̆ım yerden devam etmek istiyorum. Gidebildiğim yere kadar gideceğim. Televizyonda gördüm yaşlı bir teyze üniversite mezunu olmuştu. Neden ben de olmayayım. Okumanın yaşı yok ki..." (Ceylan).}

Kadın kursiyerlerin bir kısmı da yaş olarak biraz daha küçük olsaydım, sağlık sorunlarım olmasaydı çok farklı cevaplar verebilirdim diye görüş belirtmiştir.

\begin{abstract}
"Daha neler yapabileceğimi tam olarak düşünmedim, ama bu kursa katılmak kendime olan güvenimi arttırdl. Yaşım ve sağllğım müsait olursa, belki daha farklı şeyler yapabilirim artık." (Zeynep).
\end{abstract}

\section{Sonuç, Tartışma ve Öneriler}

Kadınlar, bir toplumun aynasıdır. Gelişmiş bir toplum için, kadınların eğitim düzeyleri yüksek olmalıdır. Gelişmiş ülkelerde okuryazarlık sorunu oldukça düşük seviyelerdeyken, gelişmekte olan bir ülke olarak Türkiye, 
okuryazarlık oranını arttırabilmek için uzun yıllardır çabalamaktadır. Özellikle, kadınların bu konudaki mağduriyeti erkeklerden çok fazladır. Yapılan okuma yazma seferberliklerinde kadınların sayısı her zaman fazla olmasına rağmen, hala erkeklere oranla okuma yazma bilmeyen kadınların fazlalığı, katılım noktasındaki sorunları da ön plana çıkarmaktadır. Paralel olarak, Sayılan, Balta ve Şahin (2002) Ankara'nın gecekondu bölgelerinde yaşayan her beş kadından birinin okuma yazma bilmediğini, Yıldız (2011) da çalışmasında okuma yazma kurslarına katılan kursiyerlerin büyük bir bölümünün kadınlar tarafından oluştuğunu tespit etmişlerdir. Bu durum okuryazar olamama sorununun daha çok bir kadın sorunu olduğuna ilişkin tespitlerle örtüşmektedir. Yıldız, Ateş, Yıldırım ve Rasinski (2011), Türkiye'de kadınların okur yazar olamamasının temel nedeninin toplumsal cinsiyet algısından kaynaklanan eşitsizlikler olduğunu; toplumsal cinsiyet rollerine ilişkin düşünce ve tutumların oluşmasında kültürün önemli bir faktör teşkil ettiğini ifade etmişler ve bu haliyle Türkiye'de kadın okumaz yazmazlığının toplumsal ve kültürel temelde kadına bakış açısıyla yakından ilgili olduğunu öne sürmüşlerdir. Bununla birlikte 21. yüzyılda hala okuma yazma bilmeyenlerin bulunması kurslara katılım noktasında daha dikkatli araştırmalar ve etkinlikler yapılması gerektiğini de ortaya koymaktadır (Gökçe, 2016).

$\mathrm{Bu}$ çalışmada yetişkin eğitimi kapsamında kadınların okuma yazma kurslarına katıldıktan sonraki hayatlarındaki değişimler incelenmiştir. Çalışmanın birinci alt probleminde kadın kursiyerlerin okuma yazma kursuna katılma sebeplerinin neler olduğu sorusuna yanıt aranmıştır. Katılımcıların kursa katılma sebebi olarak çok farklı nedenler öne sürdüğü, bunların başında yazılı ve görsel medya araçlarındaki yazıları okuyabilmek ve günlük hayattaki işlerini kolaylaştırmaya yönelik faaliyetlerde zorluk yaşamamak olduğu tespit edilmiştir. Gökçe ve Yıldız (2018) da çalışmalarında okuma yazma bilmeyen kadınların okuma yazma kurslarına katılmama nedenlerini araştırmışlardır. Araştırma sonuçlarına göre çocuk bakımı ve gündelik ev işleri, yaşlılığa bağlı sebepler, başarısızlık korkusu, iş kaynaklı etmenler ve yakın çevrenin hoş karşılamaması gibi nedenlerden dolayı kadınlar okuma yazma kurslarına katılmamaktadır. Gökçe ve Yıldız (2018) bu sorunu ataerkil toplumsal yapı ile ilişkilendirmişlerdir. Araştırma sonuçlarından kadın kursiyerlerin kursa katılmadaki önceliklerinin gündelik yaşamlarında okumaz yazmazlığın getirmiş olduğu sorunların üstesinden gelebilmek olduğu anlaşılmaktadır. Bununla birlikte kursa katılımlarda, kursiyerlerin toplumda kendilerinin de var olduğunu kanıtlaması ve okuma yazma bilmemenin vermiş olduğu baskıdan kurtulmak istemesi gibi sosyal olguların da etken olduğu söylenebilir.

Araştırma sonuçlarında dikkat çeken hususlarda biri katılımcıların neredeyse tamamının ebeveynleri okuma yazma bilmemeleridir. Sadece iki kişinin babası okuryazardır. Bu durum okuryazar olmakta ailenin önemini ortaya koymaktadır. Benzer şekilde Yıldız (2011), okuma yazma kurslarına katılan yetişkinlerin çevrelerinde daha fazla sayıda okuryazar yetişkinlerin olmasının onların okuryazarlık düzeylerinin gelişmesinde etkili olabileceğini ifade etmiştir.

Çalışmanın ikinci alt probleminde kadın kursiyerlerin okuma yazma kursuna katıldıkları süreç boyunca ailelerinden ve yakın çevrelerinden nasıl tepki aldıkları araştırılmıştır. Araştırma sonuçlarında kadınların okuma yazma kurslarına katılmalarında ailelerinin genellikle destek olduğu ve eşleri daha yüksek okuma yazma düzeyine sahip olan kadınların eşlerinin özellikle teşvik ettiği görülmüştür. Kadınlar eşlerinden gördükleri desteği aynı oranda komşularından ve arkadaşlarından görememektedir. Katılımcıların yarısının komşu ve arkadaşları teşvik edici olmak yerine heves kırıcı bir tavır takınmışlardır. Katılımcıların bir kısmı, aslında okuma yazma bilmemelerine rağmen daha önceki seferberlikler kapsamında açılan kurslara katılmadıklarını belirtmişlerdir. Sebep olarak yaşlarını göstermişlerdir. Yaşa bağlı olarak öğrenme çabalarının karşılıksız kalacağını düşünmüşler ve diğer kursiyerler ve komşularınca da okuma yazma kursunda başarısız olduklarında alay edileceğini düşünmüşlerdir. Bu sebepten önceki kurslara gelmedikleri için şu an pişman olduklarını da belirtmişlerdir. Bu durum katılımcıların kent yaşamında olmalarına rağmen çoğunun sosyo-ekonomik düzeyi düşük mahallelerden gelmeleri nedeniyle, yakın çevrelerinin eğitim konusunda yeterince bilinçli olmamasından kaynaklanabilir. Elde edilen bu sonuç Beder (1990) ve Çağlayan'ın (2016) elde ettiği yetişkinlerin okuma yazma kurslarına katılmama sebepleriyle benzerlik göstermektedir. Bulut (2015) da Ana-Kız Okuldayız Okuma-Yazma Kampanyasının çözümlenmesine ilişkin çalışmasında, Türkiye'de kent merkezlerinden kırsala gidildikçe okuryazar oranının düştüğünü, toplam okumazyazmazların dörtte birinin göç alan illerde yaşadığını ve dolayısıyla okumaz yazmazlığın aynı zamanda sosyokültürel nedenleri olduğunu belirtmektedir. Eğitimden yoksun kalmış kadınların toplumsal hayatta var olabilmeleri, kendilerini ifade edebilmeleri, okuyup yazabilmeleri için yakın çevrelerinden destek görmeleri gerekmektedir. Dolayısıyla bu sonuç, örgün eğitimden yararlanamayan veya herhangi bir nedenle eğitimini yarıda bırakmak zorunda olan kadın yetişkinlerin eğitiminde sosyal çevrenin önemli olduğunu ve eğitim gören yetişkinlerin yakınlarının da bilinçlendirilmesi gerektiğini ortaya koymaktadır.

Çalışmanın üçüncü ve dördüncü alt problemlerinde, okuma yazma kursuna katıldıktan sonra kadın kursiyerlerin günlük hayatlarında ve geleceğe yönelik planlarında ne gibi değişiklikler olduğu incelenmiştir. Kurslara devam eden kadın kursiyerler, pazarda, markette, manavda etiketleri okuyabildiklerini, otobüse binerken zorluk çekmediklerini belirtmişlerdir. Bu da okuma yazma bilmenin günlük hayatta birçok kolaylık sağladığını göstermektedir. Ayrıca kadınların, ortaokul, lise bitirme ve yeni iş yeri kurma hayallerini anlatmaları onlara bu kursun yeni bir yaşama aşkı verdiğini göstermektedir. Ayrıca katılımcılar aynı kurs tekrar açılırsa okuma yazma düzeylerini ilerletmek ve hızlandırmak için tekrar geleceklerini belirtmişlerdir. Robinson-Pant (2004) kadınlara yönelik okuryazarlık kurslarının aile planlaması ve çocuk yetiştirme programları gibi sosyal ve bireysel gelişim faaliyetleri için de bir başlangıç noktası olduğunu, dolayısıyla bu kurslara katılan kadınların gelecekte kendilerini geliştirmeye yönelik olumlu bakış açıları kazandığını belirtmiştir. Yıldız ve diğerleri (2011) de okuryazar olamayan kadınların yaşadıkları sıkıntılardan, okuryazar olmaları durumunda hayatlarında nelerin değişeceğine ilişkin düşüncelerinin tahmin edilebileceğini belirtmişler ve çalışmasındaki katılımcıların okuryazar oldukları zaman, bir yerden bir yere rahatça gidebileceklerini, sağlıkla ilgili işlemlerini sorun çekmeden 
yerine getirebileceklerini, çocuklarının eğitimine daha fazla destek olabileceklerini, daha iyi şartlarda yaşayacakları ve en önemlisi herkes için sıradan sayılabilecek günlük yaşamdaki birçok şeyi başkalarına bağımlı olmadan gerçekleştirebileceklerini ifade etmişlerdir.

Okuma yazma oranlarının bu derece yükselmesinde, okuma yazma seferberlikleri neticesinde, köylerde, kasabalarda, şehir merkezlerinde ve hemen hemen her mahallede kursların açılması, ulaşım problemlerinin kısmen giderilmesi, kurs öğretmenlerinin de okuldaki mesai saatlerinin dışında kalan zamanlarda, okul sonrası zamanlarda bu kursu vermesi de etkili olmuştur. Halk Eğitimi Merkezi bünyesinde açılan kurslarda, kursiyer sayısı asgari 12 olmak zorundayken, okuma yazma kurslarında herhangi bir yerleşim birimde okuma-yazma bilmeyen bir kişi bile olsa kursların sistem üzerinden planlanmasına onay verilebilmesi de konuya verilen ehemmiyeti göstermektedir. $\mathrm{Bu}$ hususta okuma yazma bilmeyen yetişkinlerin kurslara katılımlarının sağlanması için gerekli duyuru ve tanıtımların yapılması ve kamuoyunun bilinçlendirilmesi önemlidir. Robinson-Pant, (2004) de kadınların eğitiminin yoksul ailelerin yaşam standartlarının geliştirilmesinde anahtar bir rol oynadığını ve bu eğitimlerin yapılmasında ve duyurulmasında hükümete ve gelişim kuruluşlarına büyük görevler düştüğü ifade etmiştir.

Araştırmada kadın kursiyerlerin okuma yazma kursuna katıldıktan sonra gündelik hayatlarını kolaylaştırdıkları ve geleceğe yönelik planlarında olumlu değişmeler olduğu tespit edilmiştir. Ancak mevcut istatistik sonuçları Türkiye'de halen daha kadın okumaz-yazmazlık oranlarının yüksek olduğunu göstermektedir. Bununla birlikte sosyal baskı, evin sorumlulukları, tanıtım yetersizliği, ulaşım ve kurs merkezlerinin uzaklığı gibi nedenlerden dolayı kadınlar bu kurslara katılım sağlayamamaktadır. $\mathrm{Bu}$ sonuçlar doğrultusunda uygulamaya yönelik şu önerilerde bulunulabilir. Kurslara katılımın çoğalması için, kurs merkezlerinin sayısı daha fazla artırılabilir. Kadınların akşam kursa gelmekte sıkıntı çektiği zamanlarda, eşleri ve çocukları için de farklı kurslar düzenlenebilir. Şehir merkezlerinden uzak yerleşim yerlerinde ikamet eden ve kurslara katılmak isteyenler bireyler için öğretmen görevlendirmeleri, ders ortamı ve gerekli araç-gereçlerin temini adına yerel yönetim, gönüllü kuruluş ve sivil toplum örgütleri ile iş birliğine gidilebilir. Araştırma sonuçlarından kadın kursiyerlerin okuma yazma öğrendikten sonra eğitimlerine devam etmek ve kendilerini geliştirmek istedikleri ve bu bilgilerini iş sahibi olma, ehliyet alma gibi farklı alanlarda kullanmak istedikleri anlaşılmaktadır. Bu nedenle, kursiyerler öğrendiklerini işe koşabildiklerinde motivasyonları artacağı için, bazı dersler uygulamalı olarak yapılabilir. Ayrıca bu kursları tamamlayan yetişkinlerin kurs merkezleri ile ilişkilerinin devamını sağlayıcı çeşitli önlemler alınmalıdır. Kurs bitiminde onların becerilerini geliştirmeye dönük, okuma salonları, ücretsiz ya da ödünç kitap alabilecekleri imkânlar, rehberlik ve yönlendirme hizmeti sunacak birimler gibi destekleyici araç ve ortamlar sağlanmalıdır.

\section{Kaynakça}

Altunya, N. (2009). Eğitim hakkı ve yetişkin eğitimi. (Derleyen: A. Yıldız ve M. Uysal). Yetişkin ĕgitimi kuramdan uygulama (s. 317-337). İstanbul: Kalkedon Yayınları.

Beder, H. (1990). Reasons for non-participation in adult basic education. Adult Education Quarterly, 40(4), 207-218. doi.org/10.1177/0001848190040004003

Bulut, S. F. (2015). Ana-kız okuldayız okuma-yazma kampanyası'na ilişkin bir çözümleme. (Yayımlanmamış yüksek lisans tezi). Ankara Üniversitesi, Eğitim Bilimleri Enstitüsü, Ankara.

Erçetin, Ş. Ş. ve Arifoğlu, A. (2016). Herkes için eğitim 2015 hedefleri ve Türkiye. Bartın Üniversitesi Eğitim Fakültesi Dergisi, 5(2), 223-246.

Freire, P. (2018). Ezilenlerin pedagojisi (Çev. D. Hattatoğlu ve E. Özbek). 18. Bask1. İstanbul: Ayrıntı.

Creswell, J. W. (2007). Qualitative inquiry and research desing: choosing among five approaches. 2nd Press. SAGE Publications.

Çağlayan, A. A. (2016). Yetişkinler okuma yazma öğretimi ve temel eğitim programını tamamlayan bireylerin okuma yazma düzeylerinin incelenmesi. (Yayımlanmamış yüksek lisans tezi). Niğde Ömer Halisdemir Üniversitesi, Eğitim Bilimleri Enstitüsü, Niğde.

Gökçe, N. (2016). Kadınların okuma yazma kurslarına katılmama nedenleri ve karşılaştıkları güçlüklere baş etme stratejileri. (Yayımlanmamış yüksek lisans tezi). Ankara Üniversitesi, Eğitim Bilimleri Enstitüsü, Ankara.

Gökçe, N. ve Yıldız, A. (2018). Türkiye'de okuma-yazma bilmeyen kadınlar ve okuma-yazma kurslarına katılmama nedenleri: "Ne edeyim okumay1, hayatım mı değişecek?”. Kastamonu Education Journal, 26(6), 2151-2161. doi:10.24106/kefdergi.2737

Holton, E. F., Swanson, R. A. \& Naquin, S. S. (2001). Andragogy in practice: Clarifying the andragogical model of adult learning. Performance Improvement Quarterly, 14(1), 118-143.

Knowles, M. (1996). Andragogy: An emerging technology for adult learning. In Malcolm, Tight (Ed.), Education for adults (pp. 53-70). London: Routledge.

Knowles, M. S. (1980). The modern practice of adult education: Pedagogy to andragogy (2nd Ed.) New York: Cambridge University Press.

Köksal, S. (2017). Yerel yönetimlerde halkın eğitimi ve hayat boyu ögrenme faaliyetleri. (Yayımlanmamış Yüksek Lisans Tezi). İstanbul Aydın Üniversitesi, Sosyal Bilimler Enstitüsü, İstanbul.

Merriam, S. (2004). The changing landscape of adult learning theory. In J. Comings, B. Garner, \& C. Smith (Eds.), Review of adult learning and literacy: connecting research, policy, and practice (pp. 199220). Mahwah, NJ: Lawrence Erlbaum Associates.

Merriam, S. B. (2017). Adult learning theory: Evolution and future directions. PAACE Journal of Lifelong Learning, 26, 21-37. 
TÜİK, (2018). Okuryazarlık ve cinsiyete göre nüfus, 20082018. (Erişim: 10.09.2019) http://tuik.gov.tr/presstatistiktablo.do?istab_id=134 2

Okçabol, R. (1994). Halk eğitimi. İstanbul: Der Yayınları.

Patton, M.Q. (2002). Qualitative research \& evaluation methods (3rd ed.). Thousand Oaks, CA: Sage.

Papen, U. (2005). Adult literacy as a social practice. London: Routledge.

Robinson-Pant, A. (Ed.). (2004). Women, literacy and development: Alternative perspectives. London: Routledge.

Sabah, Ş. (2006). Okuma yazma kursuna katılan yetişkin kadınların eğitim öncesi ve sonrası davranışsal sonuçların incelenmesi. (Yayımlanmamış Yüksek Lisans Tezi). Maltepe Üniversitesi Sosyal Bilimler Enstitüsü, İstanbul.
Sayılan, F., Balta, E. ve Şahin Ö. (2002). Ankara'nın gecekondu mahallelerinde yaşayan okumaz yazmaz. ve işsiz kadınların tespiti araştırmast. Ankara: UNDP-KSSGM-KASAUM

Şimşek, H. ve Yıldırım, A. (2011). Sosyal bilimlerde nitel araştırma yöntemleri. Ankara: Seçkin Yayıncılık.

Yıldız, A. (2009). Yetişkin okuryazarlığı. (Derleyen: A. Yıldız ve M. Uysal). Yetişkin eğitimi kuramdan uygulama (s. 353-372). İstanbul: Kalkedon Yayınları.

Yıldız, A. (2011). Okuma-yazma kurslarında okuma-yazma öğreniliyor mu?. Kuram ve Uygulamada Eğitim Bilimleri Dergisi, 11(1), 403-421.

Yıldız, M., Ateş, S., Yıldırım, K. ve Rasinski, T. (2011). Okumaz yazmaz Türk kadınların perspektifinden okuryazarlık ve okumaz yazmazlık: Fenomonolojik bir çalışma.Uluslararası Insan Bilimleri Dergisi, $8(1), 440-459$. 